\title{
AAOIFI Standartları ve Türkiye Katılım Bankalarında Uygulanabilirliği
}

\section{AAOIF Standards and Its Applicability in Participation Banks of Turkey}

\author{
Faruk Ağkan a,*

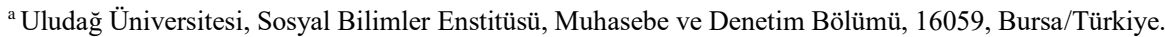 \\ ORCID: 0000-0001-8104-0589
}

\section{MAKALE BİLGISI}

\section{Makale Geçmişi:}

Başvuru tarihi: 07 Kasım 2017

Düzeltme tarihi: 26 Ocak 2018

Kabul tarihi: 19 Şubat 2018

\section{Anahtar Kelimeler:}

İslami Finans

Katılım Bankacılığı

Faizsiz Bankacılık

AAOIFI

Katılım Bankacılığı Muhasebesi

\section{ARTICLE INFO}

\section{Article history:}

Received 07 November 2017

Received in revised form 26 January 2018

Accepted 19 February 2018

\section{Keywords:}

Islamic Finance

Participation Bank

Interest Free Banking

AAOIFI

Interest Free Banking Accounting
ÖZ

İslamiyet'in faizi haram kılması İslam ülkelerinin diğer ülkelerden farklı bir finans sistemine itmiştir. İslami prensipler eksenli ortaya çıkan faizsiz bankacılık fikri tüm dünyada uygulanan bir sistem haline gelmiştir. Türkiye'ye 1984'de Albaraka Türk ile giriş yapan ve katılım bankaları adını alan faizsiz banka sistemi hızlı bir büyüme göstermiştir. 1991 yılında İslami finans kuruluşlarının muhasebe ve raporlama standartlarının belirlemek amacıyla kurulan İslami Mali Kuruluşlar Muhasebe ve Denetleme Kurumu (AAOIFI) tarafindan yayınlanan standartlar Türkiye'de aktif olan katılım bankalarının çoğunun bu standartları uygulayan ülke veya kurumlarla ortaklık kurmuş olması ekonomimiz üzerindeki etkisini arttırmıştır. Bu nedenle AAOIFI ile Türkiye Katılım Bankaları birliği (TKBB) arasında AAOIFI muhasebe, denetim ve etik standartlarının Türkçeye çevrilmesi için görüşmeler yapılmış ve 2019 yılında çevirinin tamamlanıp ülkemizde uygulanması beklenmektedir.

\section{A B S T R A C T}

The prohibition of interest in Islam has pushed Islamic countries into a different financial system than other countries. The idea of interest-free banking, which is based on Islamic principles, has become a system applied all over the world. The interest-free banking system, which entered Turkey with Albaraka Türk in 1984 and took the name of participation banks, showed a rapid growth. Standards published by The Accounting and Auditing Organization for Islamic Financial Institutions established in 1991 to set accounting and reporting standards for Islamic financial institutions and the majority of the active participation banks' in Turkey having established partnerships with countries or institutions implementing these standards has increased the impact on our economy. Negotiations were made between AAOIFI and Turkish Participation Banks Association (TKBB) to translate AAOIFI accounting, auditing and ethical standards into Turkish. In 2019, translation is expected to be completed and implemented in our country.

\section{Giriş}

Fon açı̆̆ı olanlarla fon arz ederek gelir elde etmek isteyen kişilerin buluştuğu karmaşık sisteme 'Finansal Sistem' denmektedir. Dünyada finans kurumlarının temelini teşkil eden faizin İslam dininde haram kılınmış olması Müslüman ülkelerinde ayrı bir finans sisteminin oluşumuna neden olmuştur. İslami banka, katılım bankaları veya özel finans kuruluşları adıyla anılan bu finans kuruluşları faizsiz, İslami esaslara uygun işlem yapmaları dolayısıyla diğer finans kuruluşlarından ayrılmaktadırlar.
İslamiyet'te faiz; nakit ve nakit benzerleri ile yiyecek, içecek mallarında verilenden fazlasının alınması işlemidir. Bir hadis-i şerifte; "Altın altınla, gümüş gümüşle, buğday buğdayla, arpa arpayla, hurma hurmayla, tuz tuzla başa baş misliyle peşin olarak satılır. Kim arttırır veya arttırılmasını talep ederse faize girmiş olur. Bu işte, alan da veren de aynıdır" (Müslim, ts., Müsakat, 82) şeklinde buyrularak faizi alanın ve verenin aynı konumda olduğu belirtilmiştir. İslamiyet beşer tabakaları arasındaki ekonomik dengeyi faizin haram olması ve zekâtın farz kılınması ile

\footnotetext{
* Sorumlu yazar/Corresponding author.

e-posta: farukagkan4916@gmail.com
} 
düzenlemiştir. Nitekim İslam tarihinde bu iki düstura ittiba edildiğinde İslam memleketlerinde refah düzeyi bulundukları dönem için en yüksek seviyeye çıktığı görülmektedir.

Son yıllarda Dünya ekonomisindeki payı hızlı bir şekilde artan ve 2007-2008 krizinden faizle çalışan bankaların büyük maddi kayıplarına rağmen, İslami bankaların bu krizi neredeyse kayıpsız geçirmeleri katılım bankacılığı üzerine yapılan bilimsel araştırmaları da artmıştır. Yapılmış olan bilimsel çalışmalar üzerinde yapılan literatür taraması sonucunda:

Sellami ve Tahari (2017), Finansal Kuruluşlar için Muhasebe ve Denetim Organizasyonu (AAOIFI) tarafindan yayınlanan standartların Orta Doğu ve Kuzey Afrika ülkelerindeki 38 İslami bankada 203 kriter ile uyumunu incelemişlerdir. Bu ülkelerde hem Uluslararası Muhasebe Standartları(IFRS) hem de AAOIFI tarafindan yayınlanan standartlara(AAOIFI FAS) uyma zorunluluğu bulunmaktadır. Yaptıkları araştırma sonucunda standartlara uyma yönünden 203 kritere en yüksek varyansa Bahreyn sahip olmuş, sonra sırasıyla Suriye, Ürdün, Katar, Yemen, Filistin ve sudan gelmektedir.

Siswantoro (2015), öğrenci perspektifinden İslam muhasebesinin algısı ve farkındalığ $\breve{1}_{1}$ üzerine yaptığ çalışmasında; Endonezya'nın dünyada en büyük Müslüman nüfusa sahip olan ülkesi olması nedeniyle İslam muhasebesine rağbetin hızla arttığını klasik bankaların İslami finans kuruluşlarına dönüşmekte olduklarını belirtmiştir. Uygulama kısmında ise öğrencilerin çoğunun İslam muhasebesinden haberdar olmadığı ve en dikkat çekici bulgu olarak da Müslüman öğrencilerin gayr-1 Müslim öğrencilere nazaran İslam muhasebesi hakkında daha az bilgiye sahip oldukları sonucuna varmıştır.

Tenekeci (2017), Katılım bankacılığının finansal istikrara etkisi üzerimde yaptığı araştırma sonucunda; faizin ekonomik kriz riskini arttırdığını belirterek faizsiz bankacılığın finansal istikrara olumlu etki yapacağını belirtmiştir. Ayrıca faizsiz bankacılığın faiz oranlarının düşmesine, mütedeyyin kişilerin birikimlerinin ekonomiye kazandırılması ve banka müşterisi olarak bankacılık sektöründe müşteri portföyünün artış göstermesine, Reel sektör fonlaması yapıldığından finansal istikrarın korunmasına, doğrudan istihdam ve reel sektörde istihdam artışı ile ülkemizdeki işsizliği düşmesine, yatırımcılara alternatif finans imkânları sunduğunu belirtmiş ve Katılımı bankası sayısında, pazar payında, aktiflerindeki artışı delil olarak göstermiştir.

Erkuş ve Çenberlitaş (2016), İslami finans araçlardan olan sukukların muhasebeleştirilmesi üzerine yaptıkları araştırmada sukukun türleri açıklamışlardır. Ancak muhasebeleştirmede henüz daha İslami Mali Kuruluşlar Muhasebe ve Denetleme Kurumu (AAOIFI) tarafindan sukuk muhasebeleştirilmesine dair standart yayınlanmadığ için Uluslararası Finansal Raporlama Standartları (UFRS) 7 ve 8 ile uygulamalarını yapmışlardır.

Torun (2013), faizsiz bankacılıkta risklere karşı aktif ve pasif yönetimi üzerine yaptığı çalışma sonucunda; faizsiz bankacılığın klasik banka anlayışına nazaran köklü bir tarihsel geçmişi olmamasına rağmen son sekiz yılda sürekli ve hızlı bir şekilde müşteri portföyünü arttırmakta olan faizsiz bankalar; faizle işlem yapan klasik bankaların risklere karşı yaptığı bilanço dışı işlemleri İslami kısıtlamalar nedeniyle kullanamamaktadırlar. Bundan dolayı risklere karşı aktif- pasif yönetimi ile risk yönetimi yapmaktadırlar.

Baykara (2012), katılım bankalarında etkinlik ve verimlilik analizi isimli çalışmasında; Türkiye'de faizsiz bankacılığın 30 yıllık bir geçmişi olduğunu ve sürekli olarak çift haneli bir büyüme oranıyla hızlı bir büyüme gösterdiğini ve en hızlı büyüyen sektör olduğunu belirtmiştir. TOPSIS yöntemiyle yapmış olduğu uygulama sonucunda ise; Türkiye'deki katılım bankalarında etkinlik ve verimliliğin birbiriyle doğru orantılı olmadığı ve bankalarda yıllara göre farklı etkinlik ve verimlilik oranları gösterdiğini belirtmiştir. Örneğin Kuveyt Türk katılım bankasının etkinlik skorları; 2008 yılında 0,4009, 2009 y1lında 0,3038, 2010 yilında 0.558, 2011 yılında ise 0,8694 olarak hesaplanmıştır.

Dinç (2016), katılım bankaları danışma kurullarının kurumsal yönetim olarak değerlendirilmesi isimli makale çalışmasında AAOIFI Yönetişim standartlarını irdelemiştir. AAOIFI standartları Danışma Kurulu örgütlemesi ile beraber, İç kontrol veya teftiş kurulu gibi bir örgütleme yapısını da tavsiye etmektedir. Çalışma sonucunda Türkiye'de katılım bankalarının danışma kurullarına AAOIFI sisteminin uygulanabileceği belirtilmiştir.

Yatbaz (2015), katılım bankalarında zekât ve zekât muhasebesi üzerine yaptığı çalışmasında; AAOIFI tarafından yayınlanan şer'i standartlardan zekât standardı üzerine çalışmasını şekillendirmiştir. Zekât muhasebesi bölümünü ise; yine AAOIFI tarafindan yayınlanan muhasebe standartlarından FAS 9 zekât muhasebesi standardını ele almıştır. Ancak Türkiye'de mevcut durumda bu standartları uygulamak mümkün olmamakla beraber rehber standartlar olarak kullanıldığını belirtmektedir.

Güney (2015), İslami finansta şer'i yönetim uygulamaları üzerine yaptığı çalışmasında AAOIFI yönetişim standartlarını da ele almıştır. Çalışmasında yayınlanmış olan 5 yönetim standardının birbirini tamamlayıcı bir nitelik taşıdığı ve bu yüzden de bu standartlarının tamamının aynı anda uygulanması gerektiği belirtilmiştir.

\section{2. İslami Finans ve Tarihsel Gelişimi}

Dünyada finans kurumlarının temelini teşkil eden faizin İslam dininde haram kılınmış olması Müslüman ülkelerinde ayrı bir finans sisteminin oluşumuna neden olmuştur. İslami banka, katılım bankaları veya özel finans kuruluşları adıyla anılan bu finans kuruluşları faizsiz, İslami esaslara uygun işlem yapmaları dolayısıyla diğer finans kuruluşlarından ayrılmaktadırlar. $\mathrm{Bu}$ nedenle İslami bankalar; mevcut sitemde İslami esaslara uygun olan yöntemleri veya kendilerine has geliştirdikleri yöntemlerle müşterilerine hizmet vermekteler. İslamiyet beşer tabakaları arasındaki ekonomik dengeyi faizin haram olması ve zekâtın farz kılınması ile sağlamıştır. Nitekim İslam tarihinde bu iki düstura ittiba edildiğinde İslam memleketlerinde refah düzeyi bulundukları dönem için en yüksek seviyeye çıktığı görülmektedir.

İslam devletinde finans işlemleri Beytülmal merkezli olarak yapılmaktaydı. Zekât ve sadakalar burada toplanır. Devlet tarafında yapılacak olan yol, çeşme, ibadethane, hamam gibi hizmetlerde kullanılmaktaydı. Ayrıca yetim, fakir ve yoksulların ihtiyaçları da buradan karşılanmaktaydı. Sahabe- 
i kiramdan olan ve hayattayken cennet ile müjdelenen Aşerei mübeşşereden olan Hz. Zübeyir bin Avvam yaşadığ devirde kendisine güvenen kişiler tarafından ona emanet edilen malları 'karz' şeklinde kabul ettiğini belirterek ticari işlerinde bunları kullanması İslamiyet'in ilk yıllarında dahi finans işlemlerinin yapıldığını göstermektedir.

Zaman geçtikçe İslam coğrafyasının genişlemesi, tebaa'nın artması; ticaret ile birlikte finans kurumlarının da gelişmesi için uygun bir zemini beraberinde getirmiştir. Emeviler döneminde emisyon ve üreticilere kredi verme işlemleri de yapmaya başlayan Beytülmal bir nevi merkez bankası görevini yürütmekteydi. Abbasiler döneminde sınırların genişlemesi sarrafların önemini arttırmış ve büyük sarraflar cehbez namıla mevduat topluyor çek, poliçe keşidesine aracılık ediyor ve hatta devlete kredi vermekteydiler. İslam dinine seçen kavimler ve fetih edilen yerleşkelerin kültürlerinden İslam'a aykırı olmayan uygulamalarım mezciyle yeni bir finans sistemi oluşturulmuş ve yeni finansal araçlar kullanılmaya başlanmıştır. Endülüs Emevi devletinin kurulması bu İslami finans araçlarının da Avrupa'ya taşınmış, bu sayede modern finans sisteminin temelleri atılmıştı.

Osmanlı zamanında ise; para vakıfları, eytam sandıkları, avarız sandıkları, lonca teşkilatları gibi yardım ve mali yapıya korumak amaçlı ekonomik girişimler karşımıza çıkmaktadır. Halk arasında yardımlaşma örfi kurallar ve akrabalık bağları temelinde yapılmaktaydı. Ayrıca Osmanlının son dönemlerinde 'Galata Bankerleri' Bankacılık faaliyetlerinde bulunmuşlardır.

20. yüzyılda ise İslam ülkelerinde mali yapıya daha çağdaş bir şekil verilmek istenmiştir. İlk defa 1942 yılında Malezya'da daha sonra 1950'lede Pakistan'da faizsiz bankacıllk teşebbüslerinde bulunulmuştur; ancak bunlar başarıya ulaşamamıştır. 1963 yılında ise Mısır'ın Mit Gamr kasabasında kırsal kesimdeki üreticileri tefecilerden kurtarmak amaçlı olarak Almanların ikinci dünya savaşından sonraki ekonomik gelişimlerinden etkilenen Ahmed enNaccar tarafindan Alman tasarruf bankalarının İslami prensiplerine uyarlanmasıyla ortaya çıkmıştır. Almanların desteğiyle kurulan bu bankadan faizsiz banka kurulma amacının öğrenilmesi desteğin kesilmesine neden olmuştur. Desteğin kesilmesinden sonra 1967'de kapanan banka arkasından gelecek olan faizsiz bankalara model olmuştur.

İlk çağdaş faizsiz finans kurumu ise Suudi kralı Kral Faysal döneminde Müslüman ülkelerin kamusal finans problemlerine çözüm sunmak amaçlı olarak 1975'de aralarında Türkiye'nin de bulunduğu ülkeler tarafindan Cidde'de kurulmuş olan İslam Kalkınma Bankası (İKB) olmuştur. Daha sonra İKB'nin özel sektöre kredi vermemesi üzerine bu boşluğu doldurmak için Suudi, Kuveytli ve Birleşik Arap Emirliklerindeki zengin Müslümanların teşebbüsüyle 1981 yılında İsviçre'nin Cenevre kentinde 'Dar Al-Maal Al-İslâmi' kurulmuştur. Bu teşebbüs orta doğuda Dallah Baraka gurubu gibi birçok grupların ortaya çıkmasına ön ayak olmuştur. Bu gruplaşmalar Faizsiz finans'ın Orta Doğu'da hızla yayılmasını sağlamıştır. Şu anda dünyada 200 'den fazla İslami Finans Kuruluşu İslami prensiplere uygun aktif hizmet vermektedir. İslami Finans Kuruluşları bünyelerinde 200.000.000.000 dolarlık bir fon kaynağı bulundurmaktadırlar. Faizsiz finans kurumlarının yanı sıra Citibank-ABD, Goldman Sachs-ABD, HSBC- İngiltere, Deutshce Bank-Almanya, Union Bank of Switzerland-
İsviçre, Amro Bank-Hollanda, Kleinwort Benson, ANZ Grindlays Avusturalya, United Bank of Kuwait ve Arab Banking Corporation gibi dünyanın büyük bankalarında da faizsiz işlemler yapılmaktadır.

İslami Finans Kurumlarının taşıdığı özellikler;

(i) Verilen hizmetlerde faiz yoktur.

(ii) Hizmetler ticaret ile bağlantılı olarak yapılmaktadır.

(iii) Kâr-zarar ortaklığı veya sermaye iştiraki şeklinde sermaye bağlantılı fon toplama ve kullandırması yapılmaktadir.

(iv) Fon kullandırılırken yapılacak yatırımlar İslam şeriatında yasaklanmamış olmaması gerekmektedir.

\subsection{Türkiye'de Faizsiz Bankacilık}

Türkiye'de mütedeyyin halk kitlesinin; temelinde faiz sistemi olan bankacılık sisteminden uzak kalmaları, birikimlerini ellerinde tutarak (yastık altı şeklinde tabir ederek), ekonomik olarak atıl konuma düşmelerine neden olmuştur. Müslüman Arap ülkelerinde bulunan zengin petrol rezervleri sermayeyi arttırmıştı. Ancak yeterli yatırım firsatlarının bulunmamasını firsat bilen Avrupa ülkeleri açtıkları faizsiz bankalarla bu sermayeyi ülkelerine çekmişlerdir. Türkiye bu gibi nedenlerden dolayı 16 Aralık 1983 tarihinde çıkarılan 83/7506 sayılı karar hükmündeki kararname ile faizsiz bankaların "Özel Finans kurumları" adıyla işlem yapabilmelerine izin vermiştir. 25 Şubat 1985 tarihinde hukuki sürecin tamamlanmasıyla Türkiye'de; 1985 yılında Albaraka Türk ve Faysal finans, 1989 yılında Kuveyt Türk Evkaf, 1991 yılında Anadolu Finans Kurumu, 1995 yılında İhlas Finans, 1996 yılında Asya Özel Finans olmak üzere toplam 6 Özel Finans Kurumu kurulmuştur. 19 Aralık 1999 tarihinde çıkarılan 4491sayılı kanun ile Özel Finans kurumları 4389 sayılı banka kanununa tabi tutulmuştur.

2001 krizinde İhlas Finans girdiği likidite sıkıntısı üzerine Bankacılık Düzenleme ve Denetleme Kurumu tarafindan faaliyet izni iptal edilmiş, Faysal Finans hisselerinin yabancı sermeye devredilmesi üzerine Family Finans ismiyle işlem görmeye başlamış. 2005 yılında Anadolu Finans Kurumu Family Finans Kurumu ile birleşerek Türkiye Finans ismiyle hizmetine devam etmiştir. 2015 yılında ise Bank Asya'nın faaliyet iznine 5411 sayılı bankacılık kanununun 107. maddesine göre son verilmiş. Daha sonra Türkiye'de faizsiz bankacılığa olan rağbetin artması ve müşteri portföyünün hızla genişlemesi üzerine 2015 yılında Türkiye'nin ilk kamu faizsiz bankası özelliği taşıyan Ziraat Katılım Bankası hizmete açılmıştır. 2016 yılında ise ikinci bir kamu bankası olan vakıf bankası da kendi bünyesinde faizsiz işlemlerin yapıldığı Vakıf Katılım Bankasını hizmete açmıştır. Türkiye'de katılım bankaların sahip olduğu mali değerlere ilişkin veriler Tablo 1'de yer almaktadır.

Tablo 1. Türkiye'deki Temel Katılım Bankacılığı Verileri, 2017

\begin{tabular}{cr}
\hline Finansal Büyüklükler & \multicolumn{1}{c}{ Değer } \\
\hline Toplam Aktif & 136.210 .000 .000 \\
Öz varlık & 11.986 .000 .000 \\
Net kâr & 461.000 .000 \\
Toplanan Fonlar & 92.502 .000 .000 \\
Kullandırılan Fonlar & 91.148 .000 .000 \\
Personel Sayısı & 14.954 \\
Şube Sayısı & 978 \\
\hline
\end{tabular}

Kaynak: TKBB (2017) 
İslami finans kuruluşlarında verilen başlıca ürün ve hizmetler;

(i) Mudaraba ve Muşaraka: İslami bankacılığın özünü oluşturan yöntemlerdir. Ancak uzun vadede getiri sağladı ̆̆ 1 için yapılan işlemler arasında çok az bir orana sahiptir.

(ii) Leasing: Finansal kiralama kanuna uygun olarak yapılan işlemler, İslamiyet'teki faiz anlayışının dışında ticari bir olgudur.

(iii) Murabaha: Müşterinin ihtiyacı olan eşya banka tarafindan müşteri adına satın alınır. Banka üzerine bir kâr payı koyarak müşteriye satar, müşteri taksitler halinde öder.

(iv) Mal karşılığı vesaikim alım-satımı: İhracatı vadeli olarak yapılmış olan bir malın belgeleri ihracatçıdan peşin para karşılı̆̆ aynı ihracatçıya satılır. Bankaya taksitlerle ödeme yapilir.

\subsection{Türkiye'de Katılım Bankacıllı̆ 1}

Türkiye'de faizsiz işlem yapan finans kuruluşlarından Ziraat Katılım ve Vakıf Katılım bankaları kamu bankaları, Albaraka Türk, Kuveyt Türk, Anadolu Finans ise özel teşebbüslerdir.

\subsubsection{Albaraka Türk}

1984 yılında kuruluş işlemlerinin tamamlandığ 1,1985 yılında hizmet vermeye başlayan Albaraka Türk katılım bankası Türkiye'de faaliyet gösteren ilk faizsiz işlem yapan finans kurumu olma özelliğini taşımaktadır. Kuruluşunda Albaraka bankası ile İslam kalkınma bankasının ön ayak olduğu girişimler ile yerli bir şirket grubu tarafından hizmete girmiştir. 2001'de Katılım Bankaları Güvence Fonu'nun oluşumuna liderlik yapan banka, 2002 y1lında bireysel bankacılığa ağırlık vermiş 2007 yılına gelindiğinde ise kaynak toplamak amaçlı ilk halka arzını gerçekleştirmiştir. 2011 senesinde yabancı ülkelere ilk şubesini açmıştır. Küresel piyasada 72 ülkede bulunan 800 e yakın banka ile kurduğu geniş muhabirlik ağıyla global çapta finans hizmeti sunmakta olan banka; biri yabancı ülkede olmak üzere toplam 213 şube ve 3.816 çalışanı ile hizmetine devam etmektedir.

\subsubsection{Kuveyt Türk}

'Kuwait Finance Hause'un 1989 yılında Türkiye pazarına girmesi ile kuruluş temelleri atılmaya başlamıştır. 'Kuveyt Türk Evkaf Finans Kurumu AŞ. unvanının 28 Şubat 1989 tarihinde Merkez Bankası'nın izniyle alınmasının ardından 31.03.1989 tarihinde hizmete başlamıştır. Önceleri Özel Finans Kurumu statüsünde hizmet vermekte olan Kuveyt Türk Evkaf Finans Kurumu, 1999 yılında çıkarılan 4389 sayılı Bankacılık Kanunun ile diğer Özel finans kuruluşları ile beraber banka statüsünü almıştır. 2006 yılına gelindiğinde ise halen taşıdığı Kuveyt Türk Katılım Bankası AŞ. unvanını alarak hizmetine devam etmiştir.

2016 yılında 'Global Finace' dergisi tarafindan yapilan araştırmalar sonucunda belirlenen 'Türkiye'nin en iyi katılım bankası unvanını alan Kuveyt Türk Katılım Bankası AŞ. Türkiye geneline yayılmış olan kurumsal yapısında 386 şube ve 5588 çalışanı ile hizmetine devam etmektedir.

\subsubsection{Türkiye Finans}

Anadolu Finans ile Family Finans kuruluşlarının birleşmesi sonucu kurulmuş olan Türkiye Finans katılım bankası, Bankacılık Düzenleme Denetleme Kurumu'nun (BDDK) 1747 sayılı kararı ile 2005 yılında faaliyete girmiştir. Türkiye'de sermayesinin tamamı yerli olan ilk katılım bankası özelliğini taşıyan Türkiye Finans, 2008 yılında hissesinin \%60'ını Suudi Arabistan'ın en gelişmiş bankası The National Commercial Bank satın almıştır. 285 şube ve 4.615 çalışanı ile faaliyetlerine devam etmektedir.

\subsubsection{Ziraat Katılım}

Türkiye'nin ilk kamu tarafindan kurulmuş olan ziraat katılım bankası,\% 99.99'u Ziraat Bankasına ait (tamamı hazineden helal fonlardan ödenmiş olduğu belirtilmiştir) 675.000.000TL sermaye ile BDDK tarafından 12 Mayıs 2015 tarihinde Resmi Gazete' de yayınlanmış olan 6302 sayılı karar ile faaliyete girmiştir. 49 şube ile hizmetine devam etmektedir.

\subsubsection{Vakıf Katılım}

Türkiye'de en son faaliyete geçen ve T.C. Başbakanlık Vakıflar Genel Müdürlüğü öncülüğünde kurulmuş olan Vakıf Katılım Bankası, BDDK'dan alınan faaliyet izninin müteakibinde 805.000.000 TL sermaye ile 27.05.2015'te Resmi Gazete' de yayınlanan 6205 sayılı kuruluş izniyle hizmete girmiştir.

\subsection{Katılım Bankalarında Muhasebe Sistemi}

Klasik mevduat bankalarından amaç ve yöntem açısından farklılık gösteren Katılım Bankalarının muhasebe sistemleri de ister istemez bazı farklılıklar arz edecektir. Ancak bu bankaların da vergi mevzuatı, TTK, BDDK gibi Üst kurumların düzenlemelerini uygulamak zorunluluğu bu farklılıkları tamamen ortadan kaldıramamışsa da en aza indirgemiştir.

\subsubsection{Muhasebe Politikalart}

Ülkemizde uygulanma zorunluluğu bulunan Uluslararası Muhasebe Standartları'nın (IAS) Türkçeye çevirisi olan Türkiye Muhasebe Standartları (TMS), Katılım Bankalarında da zorunlu olarak uygulanmaktadır. Katılım Bankalarının muhasebe politikalarının temelini oluşturan TMS'ler olmakla birlikte Uluslararası Muhasebe Standartlarında İslam ilkelerine göre işlem yapan finans kurumlarının ihtiyaçlarını tam karşılayacak standartların yayınlanmamış olması kurumlar açısından mecburi olarak bu eksiklikleri tamamlanmasını gerektirmektedir. Çünkü büyük sermayelerin yatırıldığı ve sistem içinde gerek iş gücü gerek fon kullanan ve gerekse bu finans kurumlarına fon sağlayan bir halk kitlesi bulunduğu ve bu bağlamda küçük bir yanlışlığın etkisi düşünüldüğünde bu eksikliklerin giderilmesinin büyük önem arz etmekte olduğu görülmektedir.

Merkez Bankası (TCMB) bu eksiklik ve ihtiyacı görmesi üzerine katılım bankalarının kira işlemlerinin Açık Piyasa İşlemleri (APİ) içine dâhil edilebilmesine olanak sağlamak amacıyla katılım bankaları için ayrı ek çerçeve sözleşmesi yayınlamıştır. 


\subsubsection{Hesap Planı}

Bankacılık Düzenleme ve Denetleme Kurumu tarafindan 29.01.2004 tarihinde Resmi Gazete 'de yayınlanan 'Tek Düzen Hesap Planı ve İzahnamesi Hakkında Tebliğ' yayınlanmıştır. Türkiye'de faaliyet gösteren bankaların karşılaştırılması, ülkenin ekonomik seyrinin takip edilebilmesi, verimlilik analizi, risk analizi, finansal analiz için muhasebe taraflarınca ulaşılabilinir ve kullanılabilinir bilgilerin üretilmesi için tek düzen hesap planına tüm bankalar tabi tutulmuştur. 20.09.2017 tarihli Resmi Gazete' de BDDK tarafindan Katılım Bankalarınca Uygulanacak Tekdüzen Hesap Planı ve İzahnamesi Hakkında Tebliğ yayınlanmıştır. Katılım bankalarının tek düzen hesap planında kullandıkları ana hesaplar Tablo 2'de yer almaktadir.

Tablo 2. Katılım Bankalarının Tek Düzen Hesap Planında Kullandıkları Ana Hesaplar

\begin{tabular}{cl}
\hline Hesap Kodu & Hesap Adı \\
\hline 0 & Dönen Değerler \\
1 & Krediler \\
2 & Yatırım Amaçlı Değerler ve Diğer Aktifler \\
3 & Toplanan Fonlar ve Diğer Yabancı Kaynaklar \\
4 & Özkaynaklar \\
5 & Kâr Payı Gelirleri \\
6 & Kâr Payı Giderleri \\
7 & Kâr Payı Dişı Gelirler \\
8 & Kâr Payı Dışı Giderler \\
9 & Bilanço Dışı Hesaplar \\
\hline
\end{tabular}

Kaynak: Resmi Gazete (2017b)

$\mathrm{Bu}$ tebliğin yayınlanmasındaki amaç (T.C. Resmi Gazete, 2017);

(i) Muhasebe kayıtlarında ve mali tablolardaki karmaşıklığın kaldırılması ve tekdüzen hale getirilmesi,

(ii) Mali tabloların oluşturulması ve kullanılmasında kolaylık sağlamak

(iii) Muhasebe bilgi kullanıcılarının ihtiyaç duyduğu bilgilere kolay ve doğru bir şekilde ulaşmasını sağlamak,

(iv) Denetim ve vergilendirmede kolaylık sağlamak, hile ve hata tespitini kolaylaştırmak,

(v) Finansal analiz, verimlilik analizi, risk analizi gibi çeşitli analiz ve yorumlar için ihtiyaç duyulan bilgilerin standart bir şekilde elde edilmesini sağlamak şeklinde sıralanabilir.

\subsubsection{Mali Tablolar}

Katılım Bankaları, 17.11.2012 tarihinde Resmi Gazete'de yayınlanan karar ile Türkiye Muhasebe Standartlarını (TMS) uygulama zorunluluğu getirilen kuruluşlara dâhil olması dolayısı ile TMS'ye uygun mali tablo düzenleme zorunlulukları bulunmaktadır. Bu noktadan hazırlanması gereken Mali tablolar; Finansal Durum Tablosu (Bilanço) ve Gelir Tablosudur. Ayrıca bu tabloların Bağımsız denetim yapan şirketlerinden onaylı olması da gerekmektedir.

BDDK tarafindan 20.09.2017 tarihinde 'Bankalarca Kamuya Açıklanacak Finansal Tablolar ve Bunlara İlişkin açıklama ve Dipnotlar hakkında tebliğde Değişiklik Yapılmasına Dair Tebliğ' yayınlanmıştır (Resmi Gazete, 2017a). Bu tebliğde:

(i) Finansal Durum Tablosu (Bilanço),

(ii) Nazım Hesaplar, (iii) Kâr/zarar ve diğer Kapsamlı Gelirler Tablosu,

(iv) Özkaynak Değişim Tablosu,

(v) Nakit Akış Tablosu,

(vi) Kâr Dağıtım tablosu yer almaktadır. Tüm bankalar tarafından kamuya açıklanacak finansal tablolarda bu taslakların kullanılması mecburidir.

Katılım bankaları tarafindan düzenlenen finansal tablolar; bağımsız denetim, vergi daireleri ve BDDK tarafından denetlenerek hukuki düzenlemelere uygunluğunu ve doğru bilgileri içerip içermediği kontrol edilmektedir.

\subsubsection{Mevduat Bankalarından Farklar}

Klasik mevduat bankalarından amaç ve yöntem açısından farklılık gösteren Katılım Bankalarının muhasebe sistemleri de ister istemez bazı farklılıklar arz edecektir. Ancak bu bankalarında vergi mevzuatı, TTK, BDDK gibi Üst kurumların düzenlemelerini uygulamak zorunluluğu bu farklılıkları tamamen ortadan kaldıramamışsa da en aza indirgemiştir.

Katılım bankalarını mevduat bankalarından ayıran temel olgu diyebileceğimiz faaliyetlerin faizsiz yürütülmesi hesap planının da farklılığını kaçınılmaz kılmıştır. Ancak ülkemizde Türk Ticaret Kanunu ile uygulanması zorunlu tutulan TMS, temel hatların değişimini engellemiştir. Katılım bankalarının Hesap adlarında "kâr payı" kavramının yerine mevduat bankalarında "Faiz" kavramı kullanılmaktadır. Ayrıca alt hesapların kullanımını şekil olarak değişiklik göstermektedir.

\section{3. İslami Muhasebe ve Tarihsel Gelișimi}

İslami muhasebe, İslami Şeriata uygun muhasebe kayıtlarını esas alan muhasebe şeklidir. İslami muhasebe veya İslam muhasebesi şeklinde adlandırılan bu muhasebe şekli İslam'ın üçüncü şartı olarak zekâtın emredilmesi üzerine kullanılmaya başlanmıştır. Kur'an-1 Kerimin en uzun ayeti olma özelliğini taşıyan Bakara Suresinin 282. Ayetinde mealen; "Ey iman edenler! Belirlenmiş bir süre için birbirinize borçlandığınız vakit onu yazın. Bir kâtip aranızda onu adaletle yazsın. Hiçbir kâtip Allah'ın kendisine ögrrettiği gibi yazmaktan geri durmasın; (her şeyi olduğu gibi) yazsın. Üzerinde hak olan kimse (borçlu) da yazdırsın. Rabbinden korksun ve borcunu asla eksik yazdirmasın. Şayet borçlu sefih veya akll zaylf veya kendisi söyleyip yazdiramayacak durumda ise, velisi adaletle yazdirsin. Erkeklerinizden iki de şahit bulundururun. Ĕger iki erkek bulunamazsa rıza göstereceğiniz şahitlerden bir erkek ile -biri yanılırsa diğerinin ona hatırlatması için iki kadın (olsun). Çağrlldıklarl vakit şahitler gelmemezlik etmesin. Büyük veya küçük vadesine kadar hiçbir şeyi yazmaktan sakın üşenmeyin. Böyle yapmanız Allah nezdinde daha adaletli, şehadet için daha sağlam şüpheye düşmemeniz için daha uygundur. Ancak aranızda yapıp bitirdiğiniz peşin bir ticaret olursa bu durum farklıdır. Bu durumda onu yazmamanızda sizin için bir sakınca yoktur. (Genellikle) alış veriş yaptı̆̆ınızda şahit tutun. Ne yazan ne de şahit zarara uğratılsın. Ĕger bunu yaparsanı (zarar verirseniz) şüphe yok ki bu, sizin yoldan çıkmanız demektir. Allah'tan korkun. Allah size gerekli olanı ögretiyor. Allah her şeyi bilmektedir." şeklinde buyrulmaktadır. Bu Ayet-i Kerime ile Muhasebenin temel kavramlarından başta, Sosyal Sorumluluk, Tarafsızlık ve Belgelendirme, Tam Açıklama 
gibi birçok kavram ile özdeşleșen söz konusu ayetteki bu ifadelerin tefsirinden (Can, 2008: 9);

(i) İslam dini açısından muhasebenin çok açık ilahi bir buyruk olduğu,

(ii) Kayıt zorunluluğunun borçlu ve alacaklı için ayrı ayrı zikredilmiş olmasıyla esasında çift yanlı kayıt mantığının işlendiği,

(iii) Muhasebecilik mesleğine ve noter müessesesine vurgu yapıldı̆̆ı,

(iv) Belgelemenin önem ve gereğine işaret edilerek ticari belgelere atıfta bulunulduğu,

(v) Alternatif ödeme biçim ve yöntemlerinden bahsedildiği

şeklinde bir dizi önemli saptama ve çıkarımlar yapmak mümkündür.

Kur'an "Zekâtı verin." (Bakara suresi 110. ayet) gibi emirleriyle, emredilen zekâtın miktarının belirlenmesi için; aktif miktarının ve borç miktarını gösterecek yabancı kaynakların belirlenip sahip olunan öz sermayenin hesaplanması günümüzde kullanılan Bilançonun temelini teşkil etmektedir. Ayrıca zekâtın bir senelik bir dönem için verilmesi ve o dönemin bilgilerine göre hareket edilmesi muhasebenin 'dönemsellik' ilkesini meydana getirmiştir.

Merkezi Mezopotamya'da olmak üzere hüküm süren Abbasi Devleti'nin (750-1258) 788 y1lına ilişkin devlet muhasebe kayıtları, merdiven yönteminin ilk örnekleri olarak kabul edilirken, Abbasi Devleti'ni ortadan kaldıran Moğolların, bugünkü İran'da kurdukları İlhanlı Devleti'nde (1240-1350) yöntemin daha da geliştirildiği, Osmanlı Devleti'nin (12991923) ise kuruluşunun ilk yıllarında İlhanlılara vergi ödediği ve bu mali ilişki sırasında yöntemi öğrenerek geliştirdiği, yöntemin fiilen ortadan kalktığı 1880 yılına kadar, bir devlet muhasebesi yöntemi olarak Osmanlı'da ve Orta Doğu'da kullanıldığı ifade edilmektedir (Güvemli, 2007: V).

Osmanlı Devletindeki güçlü merkezi otorite, bürokrasi hakkaniyetli vergilendirme sisteminin arkasında hiç şüphesiz güçlü muhasebe sistemi kendisini göstermektedir. Osmanlı arşivlerinden bugüne miras kalan 95 milyon adet belge ve 360.000 adet defter olduğu bilinmektedir. Söz konusu 95 milyon belgenin 15 milyonunun, 360.000 defterin de 180.000'inin muhasebe ile ilgili olduğu tahmin edilmektedir (Elitaş vd., 2008: 143).

Osmanlı devletinin ilk dönemlerinde uygulanmakta olan Tımar Sistemi'nin uygulanmasının kolaylaştırılması için Taşralarda yaşayan halkın ekonomik idari, askeri ve sosyal bilgilerin kayıt altına alınması amacıyla 'Taou Tahrir Defterleri' tutulmaktaydı. Dağılma dönemine gelindiğinde ise Osmanlı halkı arasında toplumsal çözülmeler başlamıştır. Tanzimat döneminde ise vergilerin hesaplanması için gerekli olan kişilerin sahip olduğu emlak, hayvan, arazi, meslek, dükkân gibi gelir getirici unsurların belirlenmesi ihtiyacının doğması üzerine 'Temettüat Defterleri' tutulmaya başlanmıştır. $\mathrm{Bu}$ defterler; hazırlanıldığı dönem ve bölge hakkında, ekonomik sosyo-kültürel ve demografik bilgiler açısından önemli bilgiler de içermektedir.

$\mathrm{Bu}$ dönem içinde; 'Siyakat yazısı', 'divan rakamları' ve 'merdiven yöntemi' kullanılarak tutulmuş olan 'icmal', 'mufassal' ve 'tahrir' defterleri kendi dönemlerinin en gelişmiş muhasebe kayıt sistemi olarak günümüze kadar ulaşmıştır. Osmanlı Devletindeki monarşi temelli yönetim sistemiyle beraber hüküm sürülen geniș coğrafyadaki vergilerin toplanması ve vergi kaçırma olaylarının azlığı bu mükemmeliyetin bir delili olarak gösterilebilir.

İslami muhasebe sistemi Endülüs Emevi Devletinin kurulmasıyla Avrupa'ya taşınmış klasik muhasebe sisteminin ana iskeletini meydana getirmiştir. İslam muhasebesi 15 . yüzyılda İtalya'da ortaya çıkan klasik muhasebe anlayışından daha eski bir muhasebe sistemiyken Osmanlı devletinin gerileme dönemine girmesi Avrupa ülkelerinin ise terakki etmesi üzerine İslam muhasebe sistemi de perde altına girmiştir. Müslüman ülkelerin sermeye sahibi olmalarının ardından çağdaş bir şekil alan İslami Muhasebe Sistemi günümüzde İslami Finans kuruluşlarında tekrar uygulanmaya başlanmıştır.

İslam muhasebesi 15. yüzyılda İtalya'da ortaya çıkan klasik muhasebe anlayışından daha eski bir muhasebe sistemiyken Osmanlı devletinin gerileme dönemine girmesi Avrupa ülkelerinin ise terakki etmesi üzerine İslam muhasebe sistemi de perde altına girmiştir. Müslüman ülkelerin sermeye sahibi olmalarının ardından çağdaş bir şekilde tekrar uygulanmaya başlanmıştır. İslam ülkelerinde İslami kurallara uygun muhasebe standartları yayımlamak üzere bazı kurumlar kurulmuş bunlara örnek olarak (İslami Finansal Hizmetler Kurumu) IFSB, (Malezya Muhasebe Standartları Kurulu) MASB, (Endonezya İslam Muhasebe Birliği) AAKSI, (İslami Bankacılık ve Finansal Kurumlar Genel Konseyi) CIBAFI, (İslam Ülkeleri Uluslararası Derecelendirme Ajans1) IIRA verilebilir.

\section{Finansal Kurulușlar için Muhasebe ve Denetim Organizasyonu (AAOIFI)}

Uluslararası muhasebe standartlarının İslami esaslara uygun olmaması, sukuk gibi bazı işlemler hakkında standart yayımlanmaması İslami finans kuruluşlarının muhasebe işlemlerinde uygulama problemlerine neden olması üzerine bazı İslam ülkeleri kendi bünyelerinde açtıkları kuruluşlarla İslam Şeriatına uygun standartlar yayımlamışlardır. Ancak sonraki dönemlerde küreselleşmenin etkisiyle bu standartlara da küresel çapta bir etkinlik alanı verilmesi ihtiyacı doğmuştur.

1991 yılında İslami finans kuruluşları için gerekli olan, şer'i hükümler, muhasebe, denetim ve etik değerler ve kurumsal yönetim alanında İslami kurallara uygun standartlar yayınlamak amaciyla Bahreyn'de "Accounting and Auditing Organization for Islamic Financial Institutions" (AAOIFI) ismiyle kurulan kurum Türkçeye "Finansal Kuruluşlar için Muhasebe ve Denetim Organizasyonu" şeklinde çevrilmektedir. İlk bildirisini 1993 yılında yayınlamış olan AAOIFI tarafindan şu anda yayınlanmış; 56 şer'i standart, 26 muhasebe standardı, 5 denetim standardı, 7 yönetişim standard1, 2 etik standardı olmak üzere toplam 94 standart yayınlamıştır. Çıkarılan standartlar 45 ülkede aralarında merkez bankalarının da bulunduğu finans kurumlarında, muhasebe ve denetim firmalarında kullanılmaktadır. Bu ülkelerin bir kısmında bu standartların uygulanması zorunlu iken bazılarında isteğe bağlı veya rehber konumda bulunmaktadır.

Kâr amacı gütmeyen bir kuruluş olan AAOIFI, Uluslararası Finansal Raporlama Standartları (UFRS)'den farklı olarak sadece İslami finans kuruluşları için standartlar yayımlamaktadır. Ancak İslami Finans kuruluşlarının 
bulunduğu bazı ülkelerde muhasebe işlemlerinin UFRS' ye uygunluğun zorunluluk arz etmesi bir muhasebe ikiliğini meydana getirmesi kaçınılmazdır. Bu yüzden de AAOIFI tarafindan yayınlanan standartların rehber konumunda bulunduğu ülkeler ve küresel pazarda etkin olan, pazar payına sahip olan firmalar açısından AAOIFI standartlarını UFRS çerçevesinde İslam şeriatına uygun bir şekilde yayınlamaktadir.

\subsection{AAOIFI'nın Amaçları}

(i) İslami Finans Kurumlarının muhasebe, denetim ve etik kurallarını geliştirmek,

(ii) İslami Finans Kuruluşları için gerekli muhasebe ve denetim standartlarını hazırlamak, yayımlamak, yorumlamak ve gerektiğinde tekrar gözden geçirmek,

(iii) Çıkarılan standartları uygulayan finans kurumların standartlara uyumunu denetlemek

(iv) Hedefleri doğrultusunda düzenli seminer, konferans, yayın yapmak şeklinde gösterebiliriz.

$\mathrm{Bu}$ amaçlar doğrultusunda hareket eden AAOIFI için standartların taşıması gereken en önemli özellik çıkardığı standartların İslam şeriatına uygunluğudur. İslam şeriatına uygunluğunu ise Şeriat Danışma Konseyi'ne onaylatmaktadır. Burada onay gören standartlar İslami Finans Kuruluş'larında kullanılmaya başlanır. Onay görmeyen standartlar düzeltilmek üzere tekrar incelemeye alınır.

\subsection{AAOIFI Organizasyon Yapıs1}

AAOIFI'nın belirlenen hedef, misyon ve vizyonuna ulaşmak esas alınarak organizasyon yapısı düzenlenmiştir. $\mathrm{Bu}$ çerçevede AAOIFI organizasyon yapısı Şekil 1'de verilmektedir.

Şekil 1. AAOIFI Organizasyon Yapıs1

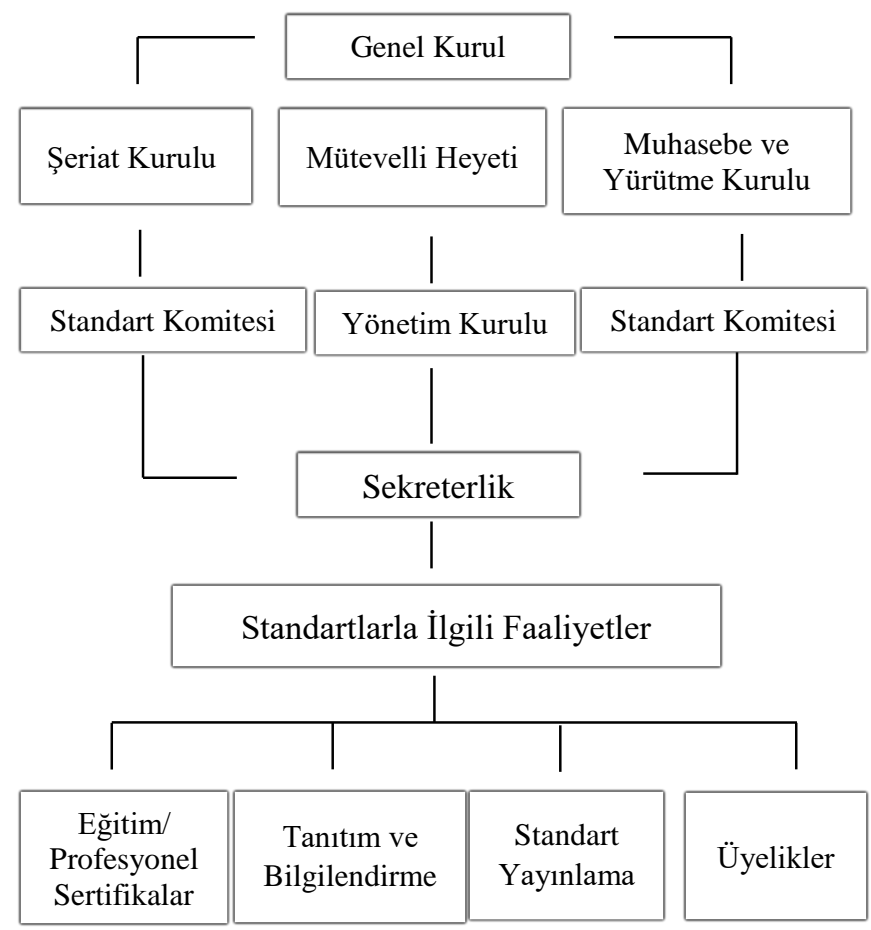

Kaynak: AAOIF (2015)
Genel Kurul; kurucu, ortak, destekleyici ve gözlemci üyeler ile düzenleyici ve denetleyici makamlardan oluşur.

Mütevelli Heyeti; her beş yılda bir Genel Kurul tarafından seçilecek on dokuza kadar üyeden ve Genel Sekreterden oluşur ve ardından gelen Yönetim Kurulunun üyeleri atanana kadar görevlerini sürdürürler. Mütevelli Heyeti, AAOIFI faaliyetlerinin gözetimini ve denetimini sağlar.

Şeriat komitesi; İslami Finans Kuruluşlarınca uygulanacak yöntemlerin, verilen ürün ve hizmetlerin İslam hukuku bağlamında değerlendirmesini yapmak amaciyla kurulmuştur.

Muhasebe Kurulu; AAOIFI tarafindan yayinlanan Muhasebe standartlarını (FAS) belirleyen kuruldur. Bu kurulda islami finans sektöründe faaliyet gösteren bütün kuruluşların temsil edilmesi ve bu kuruluşlarının bilgi, birikim ve tecrübelerinden faydalanılması amaçlanmaktadır.

Yönetişim ve etik kurulu; AAOIFI Yönetişim standartları ile Etik standartlarının çıkartmakla görevli kuruldur.

\subsection{AAOIFI Standart Yayınlama Süreci}

AAOIFI tarafından çıkarılacak veya revize edilecek olan standart için o standart konusu ile ilgili standart kurulu, Genel Sekreterlik ile beraber koordineli bir çalışma sürdürmenin yanında ihtiyaç halinde gerektiğinde dışarıdan da yardım alma imkânına sahiptirler. Standartların yayınlanmasında izlenen yol haritası;

(i) Çalışma programı veya Gündem,

(ii) Ön çalışma, araştırma,

(iii) Danışma notu,

(iv) Taslak hazırlanması,

(v) Standartların yayınlanması şeklinde belirlenmiştir.

\subsection{AAOIFI Standartlar1}

AAOIFI, 2017 y1lı itibari ile 54 Şeriat Standard1, 27 Muhasebe Standardı (AAOIFI FAS), 7 Denetim ve Yönetim Standardı ve 2 Etik Standardı olmak üzere toplam 90 Standart yayınlamıştır (AAOIFI, 2017b; bkz. Ekler).

\subsection{1. Şeriat Standartları}

AAOIFI şeriat komitesi tarafindan yayınlanan bu standartlar, İslami finans kuruluşlarının kullandığı yöntemlerin, fon toplama ve fon kullandırma araçlarının ve verilen diğer ürün ve hizmetlerin İslam hukukuna uygunluk şartlarının belirtilmesi ve kullanımında İslam hukukuna aykırılık teşkil etmemesi için dikkat edilmesi gereken hususları belirtmek amacıyla yayınlanan standartlardır. Bu standartlar daha çok fikıh ve İslam hukuku alanına girmektedir.

Bahreyn, Umman, Pakistan, Sudan ve Suriye'de zorunlu olarak uygulanmaktadır. Ayrıca devletlerin ortak kurduğu bir kurum olan İslam Kalkınma Bankası tarafından da uygulanan bu standartlar; kendi şer'i standartlarını yayınlayan Malezya ve Endonezya'da yayınlanan standartların kaynağını ve temeli teşkil etmektedir. Brunei, Dubai Uluslararası Finans Merkezi, Fransa, Ürdün, Kuveyt, Lübnan, Suudi Arabistan, Katar, Katar Finans Merkezi, Güney Afrika, Birleşik Arap Emirlikleri ve Birleşik Krallık, Afrika, Orta Asya ve Kuzey Amerika'da da İslami Finans kurumları tarafından gönüllü olarak uygulanmaktadır. 


\subsubsection{Muhasebe Standartlarl}

İslami Finans Kurumlarının konvansiyonel bankalarla arasındaki nüanslar gereği gerek verilen hizmetler gerek yapısal gerekse misyon ve vizyonları gereği ortaya çıkan bu farklılıklar gereği ayrı bir muhasebe ve raporlama stiline de ihtiyaç duymaktadırlar. AAOIFI tarafından IASB'ye yapılan islami finans kuruluşlarına uygun standartlar yayınlama çağrısı cevapsız kalmış ve AAOIFI tarafindan İslami Finans kuruluşlarına uygun standartlar yayınlanmaya başlanmıştır. AAOIFI'nın kuruluşundaki asıl amaç İslami Finans Kuruluşları için gerekli muhasebe ve denetim standartlarının yayınlanmasıdır. Bu doğrultuda AAOIFI tarafindan; 2 mali tablo standardı, 28 muhasebe Standardı olmak üzere toplam 30 standart yayınlanmıştır. AAOIFI muhasebe standartları (FAS) AAOIFI Muhasebe kurulu tarafindan düzenlenmekte ve yayınlanmaktadır. Bir kurumun sistemine uygun düzenlemeler kurumun etkinlik, kârlılık ve verimliliğine yapacağı olumlu etki kaçınılmazdır. Katılım bankalarının sistemine uygun düzenlemelerle ülkenin iktisadi büyümesine, yatırımların arttırmaya yönelik faaliyetlerini kolaylaştırarak destek olacaktır. AAOIFI muhasebe standartlarındaki amacı iki başlık altında toplayabiliriz;

(i) Belirli İslami finans ürünleri ve mekanizmaları için muhasebe işlemlerini standardize etmek,

(ii) İslami finansal kuruluşlar (IFI'ler) için mali tabloların sunumunda k1lavuz kurallar yayınlamaktır.

Bahreyn, Umman, Katar, Katar Finans Merkezi, Sudan ve Suriye'de zorunlu olarak İslami Finans Kurumları tarafindan uygulanmaktadır. İslam Kalkınma Bankası tarafından uygulanmaktadırlar. Malezya ve Pakistan'ın Ulusal Muhasebe Standartlarının temelini oluşturmaktadır. Brunei, Dubai Uluslararası Finans Merkezi, Mısır, Fransa, Kuveyt, Lübnan, Malezya, Suudi Arabistan, Güney Afrika, Birleşik Arap Emirlikleri, Birleşik Krallık, Afrika ve Orta Asya'da faaliyet gösteren İslami Finans Kuruluşları tarafindan gönüllü olarak uygulanmaktadır.

\subsubsection{Denetim, Yönetim ve Etik Standartları}

AAOIFI tarafindan yayınlanmış olan bu standartlar zorunlu bir düzenleme özelliği taşımaktan öte tavsiye standartlar olarak yayınlanmışlardır. İsteğe bağlı olarak İslami Finans kuruluşları tarafindan uygulanmaktadırlar.

\section{AAOIFI Standartlarının Türkiye'de Uygulanabilirliği}

Türkiye'de Türk Ticaret Kanunu (TTK) gereğince uygulama zorunluluğu bulunan TMS VE UFRS Türkiye'deki katılım bankalarında bu standartların uygulanma alanını kısıtlamıştır. Muhasebe kayıtları ve mali tablo hazırlanmasında esas olarak kabul edilen vergilendirme ve dış bilgi kullanıcılarının düşünülmesi Şer'i, muhasebe, denetim standartlarının uygulanmasına mani teşkil etmiştir. Ancak; yönetişim, etik standartların bunlar açısından bir engel teşkil etmemesi rehber standartlar olarak kullanılabilmelerinin önünü açmıştır.

AAOIFI standartlarının uygulanması için yeterli bir kanuni alt yapının mevcut olmamasına rağmen Katılım bankaları açısından rehber standartlar olarak uygulanmaktadır. TKBB tarafindan Şeriat standartları, KGK (Kamu Gözetim Kurumu) tarafindan ise Muhasebe, Denetim, Yönetişim ve
Etik standartların Türkçeye çevirisi yapılmaktadır (Yatbaz, 2015: 22)

AAOIFI standartlarının Türkiye katılım bankalarının uygulayıp uygulamadıkları konusunda katılım bankaları yetkilileri ile yaptığımız birebir görüşmeler sonucunda katılım bankalarının bir kısmı AAOIFI standartlarını ana ortaklığın uygulamaları gereği iç raporlama şeklinde uyguluyorken, bir kısmı ise rehber standartlar şeklinde uyguladıklarını belirtmişlerdir.

Öz kaynak; "Ay sonları itibariyle hesaplanmak üzere, katılım bankalarının ana sermaye ve katkı sermayeleri toplamından, sermayeden indirilen değerlerin düşülmesi sonucu bulunacak tutarl ifade eder. Ana sermaye; ödenmiş sermaye, kanuni, ihtiyari ve olağanüstü yedek akçeler, vergi karşılığından sonraki dönem kârı ve geçmiş yıllar kârı toplamindan oluşur. Ana sermayenin hesaplanmasında, katılım bankalarının dönem zararı ile geçmiş yıllar zararı toplamı indirim kalemi olarak dikkate alınır. Katkı sermaye; genel kredi karşılığ iştirakler ve bă̆ll ortaklıklar ile sermayelerine katılan diğer ortaklıklar sabit klymet yeniden değerleme karşılığı, kullanılan sermaye benzeri krediler, muhtemel riskler için ayrılan serbest karşılıklar ve menkul değerler değer artış fonu toplamından oluşur." (Tunç, 2010: 131).

Türkiye'de işlem yapan özel katılım bankalarının öz kaynaklarının büyük bir kısmının yabancı sermaye kaynaklı olması ve bu yabancı sermayenin de genel olarak AAOIFI standartlarını uygulayan ülke veya kurumlara ait olması bu standartların rehber standart olarak uygulanmasinı sağlamıştır. Nitekim Özel sermaye ile kurulmuş olan katılım bankalarının sermayelerini ve sermaye kaynaklarını inceleyecek olursak;

Tablo 3. 2017 Yılı İtibariyle Özel Sermayeli Katılım Bankalarının Sermaye Yapisı

\begin{tabular}{lrcr}
\hline Banka Ad1* & Sermaye Tutarı & $\begin{array}{c}\text { Yabanc1 } \\
\text { Sermaye } \\
\text { Oranı } \%\end{array}$ & $\begin{array}{c}\text { Yabanc1 } \\
\text { Sermaye } \\
\text { Tutar1 }\end{array}$ \\
\hline Albaraka Türk & 900.000 .000 & 65,99 & 593.925 .343 \\
Kuveyt Türk & 2.800 .000 .000 & 71,24 & 1.994 .720 .000 \\
Türkiye Finans & 2.600 .000 .000 & 67,03 & 1.742 .780 .000 \\
Toplam & 6.300 .000 .000 & 68.75 & 4.331 .425 .343 \\
\hline
\end{tabular}

* Vakıf Katılım ve Ziraat katılım bankaları devlet bankaları olmaları ve sermayelerinin tamamı kamu sermayesi olmasından dolayı eklenmemiştir.

Kaynak: Yazar tarafından katılım bankalarının 2017 yılına ait bağımsız denetim raporlarından derlenmiştir.

Ülkemizde özel sermaye yatırımı ile aktif faaliyette bulunan üç katılım bankasının sermayelerinin çoğunluğunu oluşturan yabancı sermayelerdir. Bu sermaye sahipleri ise Albaraka Türk için \%54,06'sı Albaraka bankacılık grubuna, \%7.84'ü İslam Kalkınma Bankasına, \%3.46 ise Alharthy ailesine aittir. $\mathrm{Bu}$ ortaklardan Albaraka bankacılık grubu AAOIFI üyesi olmakla beraber standartlarını kullanmaktadır. İslam Kalkınma Bankası da AAOIFI standartlarını uygulamaktadır. Kuveyt Türk için bakacak olursak; \%62,24'ü Kuveyt Finance House'a, \%9'u Kuveyt Sosyal Güvenlik Kurumu'na, \%9'u ise İslam Kalkınma Bankası'na aittir. Türkiye Finans sermayesi ise; \%60'lı kısmı The National Commercial Bank'a aittir. Gönüllü olarak AAOIFI standartlarını uygulamakta olan bu kuruluşların bir nevi Türkiye temsilcilikleri mahiyetini haiz Katılım Bankalarında 
uygulanma zorunluluğu bulunan Uluslararası Finansal Raporlama Standartları, Türkiye Muhasebe Standartları ve tek düzen hesap planına uygun olmak şartıyla rehber konumda AAOIFI Standartlarını da gönüllü olarak uygulamaktadırlar.

\section{Sonuç ve Değerlendirme}

Mütedeyyin halk kitlesinin fonları ekonomik döngü içine katılarak atıl kalmaktan kurtarılmış, mütedeyyin yatırımcılar faize bulaşmadan yatırımları için gerekli finans kaynaklarını bu kurumlardan temin edebilmeleri özel girişim ve yatırımları arttırmıştır. Bu bankaları kısa sürede müşteri portföylerinde büyük bir genişleme görülmüştür. Bunun sonucunda kamu tarafından da katılım bankaları açılmıştır.

Türkiye'de İlk olarak Özel Finans kuruluşları ismiyle faaliyet gösteren faizsiz finans kuruluşları Türkiye'de ekonomiye özellikle petro-dolarların çekilmesi hususunda büyük katkılar yapmıştır. Nitekim bu bankaların sermaye yapılarından bu durum görülmektedir. Ayrıca 2001 ve 2008 krizlerini çok az kayıpla geçirmeleri ülkemiz ekonomisi için büyük önem arz etmektedir.

İslam dini, hayatın her alanında düzenleme yaptığı gibi ilk başta ticaretle uğraşan kişilerin ve ekonominin çok hareketli olduğu bir yerde nazil olması nedeni ile ekonomide büyük düzenlemeler yapmıştır. Muhasebe alanında çift taraflı kayıt yapılması, borç ilişkilerinin kayıt altına alınması, noterlik ve muhasebecilik mesleği Bakara suresinin 282. ayetinde düzenlenmiştir. Sosyal Sorumluluk, Tarafsızlik ve Belgelendirme, Tam Açılama ilkelerini de bu ayet müminlere ders vermiştir. Zekâtın emredilmesi ile de dönemsellik ilkesinin ve bilançonun temeli atılmıştır.

Daha sonraki dönmelerde İslam dininin yayılması, diğer kültürlerden İslam şeriatına münafi olmayan değerler ve öğelerin mezciyle modern muhasebe sisteminin temelleri atılmıştır.

1970'li yıllarda hızlı bir şekilde büyüme gösteren faizsiz bankalarının amaç ve yöntem bakımından klasik mevduat bankalarından farklılık göstermesi ve bu farklılıklar için Uluslararası muhasebe standartları (UMS) setinde standart bulunmaması, muhasebe kaydı ve finansal tablolarda karışıklıklar doğurmuştur. Bu kurumlar için ilk önceleri bazı ülkeler ulusal çapta standart yayınlamışken küresel piyasaya yayılmış olan bankalar için yeterli olmamıştır. Bu sebeple 1991 yllında Bahreyn'de kurulan AAOIFI bugüne kadar toplam 90 standart yayınlamıştır. Bu standartlar da yaklaşık 40 ülkede zorunlu veya gönüllü olarak finans kuruluşları tarafindan uygulanmıştır.

Ülkemizde Katılım bankaları tarafindan UMS ve tek düzen hesap planı çerçevesinde muhasebe kaydı ve finansal tablo hazırlanması TTK tarafindan zorunluluk taşımaktadır. Ancak bununla beraber TKBB tarafindan AAOIFI şer'i standartlarının çevirisi yapılmış ve ilgili yerlere dağıtılmıştır. Rehber standartlar olarak UMS'lerin yetersiz kaldığ 1 noktalarda uygulanmaktadır. BDDK ile AAOIFI tarafindan yapılan protokolle bu standartların Türkçeye çevrilmesi ve faizsiz işlem yapan finans kuruluşlarında gönüllü olarak uygulanabilmesinin önünün açılması planlanmaktadır.

\section{Kaynakça}

AAOIFI (2015). Accounting, auditing and governence standards. (s. 18-37). Bahreyn: Accounting and Auditing Organization for Islamic Financial Institutions.

AAOIFI (2017a). Shariah standards for Islamic financial institutions. Bahreyn: Accounting and Auditing Organization for Islamic Financial Institutions.

AAOIFI (2017b) Standards issued. Bahreyn: Accounting and Auditing Organization for Islamic Financial Institutions. $\quad$ (Erişim: 10.09 .2017 ). http://aaoifi.com/\%D8\%A7\%D9\%84\%D9\%85\%D8\%B 9\%D8\%A7\%D9\%8A\%D9\%8A\%D8\%B1$\% \mathrm{D} 8 \% \mathrm{~A} 7 \% \mathrm{D} 9 \% 84 \% \mathrm{D} 8 \% \mathrm{~B} 5 \% \mathrm{D} 8 \% \mathrm{~A} 7 \% \mathrm{D} 8 \% \mathrm{AF} \% \mathrm{D} 8$ $\% \mathrm{~B} 1 \% \mathrm{D} 8 \% \mathrm{~A} 9-2 /$

Ansari, O. M. (2017). Audit \& sharia compliance - issues in islamic banking and finance. (Erişim: 14.10.2017). http://www.alhudacibe.com/images/Presentations\%20on $\%$ 20Islamic\%20Banking\%20and\%20Finance/Risk\%20 Management $\% 20$ and $\% 20$ Islamic $\% 20$ Finance/Audit $\% 20$ Issue \%20of\%20Islamic\%20Banking.ppt

Baykara, H. V. (2012). Katılım bankalarında etkinlik ve verimlilik analizi. Yüksek Lisans Tezi. Tokat: Gaziosmanpaşa Üniversitesi

Can A. V. (2008). Bir ayetin ışı̆̆ııda İslam dininin muhasebeye bakışı. Akademik Bakış, 15, 1-10.

Dinç, Y. (2016) Katılım bankalarının danışma kurullarının kurumsal yönetim unsuru olarak değerlendirilmesi. Islam Ekonomisi ve Finans Dergisi, 2, 83-103.

Erkuş, H., \& Çemberlitaş, İ. (2016). İslâmî finansal araçlardan olan sukuk'ların muhasebeleştirilmesi. Dicle Üniversitesi İktisadi ve İdari Bilimler Fakültesi Dergisi, 6(1), 245-262.

Gül, M. E. (2013). Faizsiz bankacılıkta risklere karşı aktif ve pasif yönetimi: Türkiye katılım bankaları üzerine bir uygulama. Yüksek Lisans Tezi. Kayseri: Erciyes Üniversitesi.

Güney, N. (2015). İslami finansta şer'i yönetim uygulamaları ve konuyla ilgili tartışmalara genel bir bakış. Türkiye İslam İktisadı Dergisi, 2, 45-69.

Mücahitoğlu, N. (2015). Türkiye'de katılım bankalarının finansal kiralamadaki yeri, diğer finansal kiralama şirketleriyle karşılaştırılması ve sektörde sukuk uygulaması beklentileri. Yüksek Lisans Tezi. İstanbul. Marmara Üniversitesi Sosyal Bilimler Üniversitesi.

Özeroğlu, A. İ. (2014). Sukuk ve Türkiye'de Sukukun Uygulanabilirliğinin Değerlendirilmesi. Tarih Okulu Dergisi, 19, 751-772.

Resmi Gazete (2017a). Bankalarca Kamuya Açıklanacak Finansal Tablolar ve Bunlara İlişkin Açıklama ve Dipnotlar Hakkında Tebliğde Değişiklik Yapılmasına Dair Tebliğ. 29 Eylül 2017 tarihli ve 30186 sayılı Resmi Gazete.

http://www.resmigazete.gov.tr/eskiler/2017/09/2017092 0M1-1.htm

Resmi Gazete (2017b). Katılım Bankalarınca Uygulanacak Tekdüzen Hesap Planı ve İzahnamesi Hakkında Tebliğ. 
29 Eylül 2017 tarihli ve 30186 sayll Resmi Gazete. http://www.resmigazete.gov.tr/eskiler/2017/09/2017092 0M1-2.htm

Sellami, Y. M., \& Tahari, M. (2016). Factors Influencing Compliance Level With AAOIFI FiO*lononancial Accounting Standards By Islamic Bankbs. (Erişim: 7.09.2017). Journal of Applied Accounting Research, www.emeraldinsight.com/0967-5426.html.

Sellami, Y. M., \& Tahari, M. (2017). Factors influencing compliance level with AAOIFI financial accounting standards by Islamic banks. Journal of Applied Accounting Research, 18(1), 137-159.

Tenekeci, M. (2017). Katılım Bankacılı̆̆ının Finansal Istikrara Etkisi: Türkiye Örneği. Yüksek Lisans Projesi. Konya: KTO Karatay Üniversitesi.

TKBB (2017). Mukayeseli tablolar. (Erişim: 13.09.2017). http://www.tkbb.org.tr/

Tok, A. (2009). Islami Finans Sistemi Çerçevesinde Sukuk (İslami Tahvil) Uygulamalart, Katılım Bankaları Ve Türkiye Açısından Değerlendirmeler. Ankara.

Tunç, H. (2010). Katılım bankacılı̆̆ felsefesi, teorisi ve Türkiye uygulaması. Nesil Yayınları, İstanbul.

Yatbaz, A. (2015). Faizsiz finansal kuruluşlarda zekât, zekât fonu ve zekât muhasebesi. Uluslararası Íslam Ekonomisi ve Finansı Araştırmaları Dergisi, 1(2).

\section{Ekler}

Tablo 4. AAOIFI FAS Muhasebe Standartları

\begin{tabular}{|c|c|c|c|}
\hline $\begin{array}{l}\text { Standart } \\
\text { No }\end{array}$ & Standart Ad1 & $\begin{array}{l}\text { Standart } \\
\text { No }\end{array}$ & Standart Ad1 \\
\hline SFA1 & Kavramsal çerçeve & FAS13 & $\begin{array}{l}\text { İslami sigorta şirketlerinin } \\
\text { artış ve eksilişleri }\end{array}$ \\
\hline FAS1 & $\begin{array}{l}\text { Mali tablo } \\
\text { sunuluşu }\end{array}$ & FAS14 & Yatırım fonu \\
\hline FAS2 & $\begin{array}{l}\text { Murabaha, satın } \\
\text { alma, sipariş verme }\end{array}$ & FAS15 & $\begin{array}{l}\text { İslami sigorta şirketlerinde } \\
\text { karş1llklar ve rezerv }\end{array}$ \\
\hline FAS3 & $\begin{array}{l}\text { Mudaraba } \\
\text { finansmanı }\end{array}$ & FAS16 & $\begin{array}{l}\text { Döviz işlemleri ve dış } \\
\text { işlemler }\end{array}$ \\
\hline FAS4 & $\begin{array}{l}\text { Muşaraka } \\
\text { finansmanı }\end{array}$ & FAS17 & Gayrimenkul yatırımları \\
\hline FAS5 & Kâr dağıtımı & FAS18 & $\begin{array}{l}\text { Konvansiyonel mali } \\
\text { kuruluşlarca sunulan } \\
\text { İslami mali hizmetler }\end{array}$ \\
\hline FAS6 & $\begin{array}{l}\text { Yatırım } \\
\text { hesaplarının } \\
\text { sahipleri ve } \\
\text { ortakları }\end{array}$ & FAS19 & $\begin{array}{l}\text { İslami sigorta şirketlerinde } \\
\text { katk1 }\end{array}$ \\
\hline FAS7 & $\begin{array}{l}\text { Salam ve paralel } \\
\text { salam }\end{array}$ & FAS20 & Ertelenmiş satış ödemeleri \\
\hline FAS8 & İcara & FAS21 & $\begin{array}{l}\text { Varlık transferlerine ilişkin } \\
\text { açıklama }\end{array}$ \\
\hline FAS9 & Zekât & FAS22 & Bölüm raporlamas1 \\
\hline FAS10 & $\begin{array}{l}\text { İstisna ve paralel } \\
\text { istisna }\end{array}$ & FAS23 & Konsolidasyon \\
\hline FAS11 & $\begin{array}{l}\text { Karşılıklar ve } \\
\text { yedekler }\end{array}$ & FAS24 & İştiraklerdeki yatırımlar \\
\hline FAS12 & $\begin{array}{l}\text { İslami sigorta } \\
\text { şirketlerinin mali } \\
\text { tablo sunumu }\end{array}$ & FAS5 & $\begin{array}{l}\text { Sukuk, hisse senedi ve } \\
\text { benzeri araçlarla yapılan } \\
\text { yatırımlar }\end{array}$ \\
\hline
\end{tabular}

Tablo 5. AAOIFI Şeria' Standartları

\begin{tabular}{|c|c|c|c|}
\hline $\begin{array}{l}\text { Standart } \\
\text { No } \\
\end{array}$ & Standart Ad 1 & $\begin{array}{c}\text { Standart } \\
\text { No }\end{array}$ & Standart Adı \\
\hline 1 & Para Birimi İşlemleri & 25 & $\begin{array}{l}\text { Sözleşmelerin } \\
\text { kombinasyonu }\end{array}$ \\
\hline 2 & $\begin{array}{l}\text { Banka Kart1, Kredi } \\
\text { kart1 }\end{array}$ & 26 & İslami sigorta \\
\hline 3 & Ödeme Araçları & 27 & Endeksler \\
\hline 4 & Borç Ödeme tesbiti & 28 & Bankacılık Hizmetleri \\
\hline 5 & Garanti & 29 & Fetva için etik talimatlar \\
\hline 6 & $\begin{array}{l}\text { Konvansiyonel bir } \\
\text { Bankanın İslami Bir } \\
\text { Bankaya } \\
\text { Dönüştürülmesi }\end{array}$ & 30 & Tevarruk \\
\hline 7 & Havale & 31 & $\begin{array}{l}\text { Belirsiz finans } \\
\text { işlemlerinde şartlar }\end{array}$ \\
\hline 8 & $\begin{array}{l}\text { Murabaha, Satın Alma, } \\
\text { Sipariş verme }\end{array}$ & 32 & Tahkim \\
\hline 9 & İcara & 33 & Vakif \\
\hline 10 & Salam ve paralel salam & 34 & İşçi ve emek \\
\hline 11 & $\begin{array}{l}\text { İstisna ve paralel } \\
\text { istisna }\end{array}$ & 35 & $\begin{array}{l}\text { Zekat Şarta bağlı } \\
\text { Yükümlülükler }\end{array}$ \\
\hline 12 & $\begin{array}{l}\text { Muşaraka ve modern } \\
\text { şirketler }\end{array}$ & 36 & Hak çatışmaları \\
\hline 13 & Mudaraba & 37 & Kredi yükümlülükleri \\
\hline 14 & Kredi belgeleri & 38 & Çevrimiçi mali hizmetler \\
\hline 15 & Juala & 39 & Rehin \\
\hline 16 & Ticari belgeler & 40 & $\begin{array}{l}\text { Yatırım Hesabi ve kâr } \\
\text { dağıtımı }\end{array}$ \\
\hline 17 & Yatırım sukuku & 41 & Reasürans \\
\hline 18 & Sahiplik & 42 & Hakların çatışması \\
\hline 19 & Kredi & 43 & İflas \\
\hline 20 & Emtia & 44 & Likidite yönetimi \\
\hline 21 & Hisse ve tahviller & 45 & Sermaye koruma \\
\hline 22 & İmtiyaz sözleşmeleri & 46 & Yatırım acenteleri \\
\hline 23 & Acente & 47 & Gelir ve kârlar \\
\hline 24 & Sendika finansman 1 & 48 & Hukuk sözleşmeleri \\
\hline
\end{tabular}
Kaynak: AAOIFI (2017b)

Tablo 6. Denetim Standartları

\begin{tabular}{clll}
\hline $\begin{array}{c}\text { Standart } \\
\text { No }\end{array}$ & Standart adı & $\begin{array}{c}\text { Standart } \\
\text { No }\end{array}$ & Standart adı \\
\hline 1 & $\begin{array}{l}\text { Denetimin hedefleri ve } \\
\text { ilkeleri }\end{array}$ & 4 & $\begin{array}{l}\text { Dış denetçi tarafindan } \\
\text { şeria' ilkelerine uyumun } \\
\text { denetlenmesi }\end{array}$ \\
\hline 2 & Denetçi raporu & & $\begin{array}{l}\text { Finansal tabloları } \\
\text { denetiminde } \\
\text { dolandırıcılık ve hilelerin } \\
\text { değerlendirilmesi }\end{array}$ \\
\hline 3 & $\begin{array}{l}\text { Denetim terminolojisi } \\
\text { şartları }\end{array}$ & 5 & \\
\hline
\end{tabular}
Kaynak: AAOIFI (2017b)

Tablo 7. Yönetişim Standartları

\begin{tabular}{clcl}
\hline $\begin{array}{c}\text { Standart } \\
\text { no }\end{array}$ & Standart Adı & $\begin{array}{c}\text { Standart } \\
\text { No }\end{array}$ & Standart Adı \\
\hline 1 & $\begin{array}{l}\text { Şeriat teftiş kurulu, } \\
\text { atama, pozisyon ve } \\
\text { raporlaması }\end{array}$ & 5 & $\begin{array}{l}\text { Şeriat teftiş kurulunun } \\
\text { bağımsılığı }\end{array}$ \\
\hline 2 & Şeriat incelemesi & 6 & $\begin{array}{l}\text { İslami Finans kuruluşları } \\
\text { yönetişim ilkeleri beyanı }\end{array}$ \\
\hline 3 & İç şeriat incelemesi & & $\begin{array}{l}\text { İslami Finansal } \\
\text { Kurumlar için Kurumsal } \\
\text { Sosyal Sorumluluk }\end{array}$ \\
\hline 4 & $\begin{array}{l}\text { İslami finans } \\
\text { kuruluşları için } \\
\text { denetim ve yönetişim } \\
\text { komitesi }\end{array}$ & 7 & $\begin{array}{l}\text { Davranışı ve } \\
\text { Bilgilendirme }\end{array}$ \\
\hline Kand
\end{tabular}

Kaynak: AAOIFI (2017b) 
Tablo 8. Etik Standartlar

\begin{tabular}{clcl}
\hline $\begin{array}{c}\text { Standart } \\
\text { No }\end{array}$ & Standart Ad 1 & $\begin{array}{c}\text { Standart } \\
\text { No }\end{array}$ & Standart Adı \\
\hline \multirow{2}{*}{1} & $\begin{array}{l}\text { İslami Finans } \\
\text { kuruluşları Denetçi } \\
\text { ve muhasebecileri } \\
\text { için Etik kodlar }\end{array}$ & 2 & $\begin{array}{l}\text { İslami Finans kuruluşları } \\
\text { çalşanları için Etik kodlar }\end{array}$ \\
\hline
\end{tabular}

Kaynak: AAOIFI (2017b) 